\title{
HUBUNGAN INFORMASI LAPORAN KEUANGAN NASABAH DENGAN KEPUTUSAN PEMBERIAN PEMBIAYAAN PADA PT. BPRS SAFIR BENGKULU
}

\author{
Fitria Wati \\ Feri Susanto \\ Program Studi Akuntansi \\ Fakultas Ekonomi Universitas Dehasen Bengkulu
}

\begin{abstract}
ABSTRAK
Fitria Wati, Feri Susanto; Tujuan dari penelitian ini adalah untuk mengetahui hubungan antara informasi laporan keuangan nasabah dengan keputusan untuk memberikan pembiayaan di PT. BPRS Safir Bengkulu. PT. BPRS Safir Bengkulu didirikan untuk menjadi unggul dan sehat di Provinsi Bengkulu, memberikan manfaat dalam pembangunan ekonomi, terutama orangorang dari provinsi Bengkulu, menyediakan layanan profesional dan kepercayaan dalam menjalankan bisnis perbankan, dan menjadi sebuah komunitas mitra bisnis, khususnya pengusaha. Dari hasil penelitian yang dilakukan menunjukkan bahwa hubungan laporan keuangan nasabah dengan keputusan untuk memberikan penyediaan pembiayaan kepada PT. BPRS Safir Bengkulu dari Juli 2014 sampai bulan September 2014 tidak semua indikator informasi memiliki hubungan yang signifikan
\end{abstract}

\begin{abstract}
Fitria Wati, Feri Susanto; The purpose of this research was to determine the relationship of the customer's financial statement information with the decision to grant financing in PT. BPRS Safir Bengkulu. PT. BPRS Safir Bengkulu established to be superior and healthy in Bengkulu Province, provide benefits in economic development, especially people of Bengkulu province, providing professional services and trust in carrying out banking business, and become a business partner community, especially employers. From the results of research conducted showed that the relationship of customer's financial statement with the decision to grant the provision of financing to PT. BPRS Safir Bengkulu from July 2014 through the month of September 2014 was not all indicators of the information has a significant relationship.
\end{abstract}

Key words: Customer's Financial Statement Information

\section{PENDAHULUAN}

Pertumbuhan dan perkembangan dunia usaha di Indonesia, tidak terlepas dari peranan pemerintah yang memberikan kesempatan pada pihak swasta ataupun perorangan untuk mengembangkan diri seluas-luasnya sejauh tidak menyimpang dari sasaran pembengunan nasional ataupun pembangunan daerah. Sasaran pembangunan nasional maupun pembangunan daerah adalah pemerataan, pertumbuhan dan stabilitas nasional, serta peningkatan kesejahteraan rakyat.

Dalam masalah pembangunan nasional maupun pembangunan daerah terutama di Propinsi Bengkulu seperti sekarang ini, dimana pemerintah menekankan pada unsur pemerataan yang akan menuju pada suatu pertumbuhan yang meningkat, maka kegiatan usaha khususnya dibidang ekonomi harus dapat menunjang hal tersebut karena bidang ekonomi salah satu unsur penting yang akan dijadikan barometer keberhasilan kebijaksanaan pemerintah daerah tersebut. 
Ini mengharuskan mereka mencari dana extra guna melaksanakan kebijaksanaa tersebut. Dan akan timbul suatu kebijaksanaan baru yaitu mendapatkan dana dengan meminjam kepada pihak lain, yang salah satunya adalah lembaga keuangan seperti bank.

Peranan bank sangat berarti dalam mempengaruhi keadaan perekonomian. Salah satu indikator penyebab terjadinya pertumbuhan ekomoni yang tidak stabil akibat dari masalahmasalah yang dihadapi oleh bank terutama banyaknya kredit atau pembiayaan yang diberikan oleh bank kepada pihak badan usaha atau perorangan yang tidak bisa dilunasi tepat waktu, piutang yang tidak tertagih ini kenal dengan kredit macet.

Salah satu upaya untuk memperkecil atau menghindari terjadinya hal tersebut, pihak bank harus melakukan analisis terlebih dahulu secara tepat dan akurat terhadap pihak-pihak yang mengajukan permohonan pemberian pembiayaan dan terus mengevaluasi dalam rangka melakukan penilaian kelayakan pemberian pembiayaan tersebut.

Salah satu syarat untuk memperoleh kredit atau pembiayaan yaitu harus mengetahui informasi akuntansi dari calon nasabah. Atas dasar informasi akuntansi dari calon nasabah, bank menilai keadaan finansial nasabah serta mempertimbangkan kelayakan dari calon nasabah.

\section{Landasan Teori \\ Bank}

Perbankkan merupakan lembaga keuangan yang memiliki peranan penting dalam kegiatan perekonomian dan merupakan suatu badan yang bergerak dalam bidang perkreditan yaitu menerima simpanan dari masyarakat dan menyalurkannya kembali dana-dana tersebut kepada masyarakat yang membutuhkannya.

Salah satu landasan hukum sistem perbankan di Indonesia adalah Undang-undang Nomor 10 Tahun 1998 mendefinisikan "bank adalah badan usaha yang menghimpun dana dari masyarakat dalam bentuk simpanan dan menyalurkannya kepada masyarakat dalam bentuk kredit dan atau bentuk-bentuk lainnya dalam rangka meningkatkan taraf hidup rakyat banyak".

Adapun jenis-jenis perbankan menurut Undang-undang Nomor 10 Tahun 1998 dapat ditinjau dari berbagai segi antara lain :

\section{Dari Segi Fungsinya}

1. Bank Sentral

Menurut UU RI No.3 Tahun 2004, bank sentral adalah lembaga negara yang mempunyai wewenang untuk mengeluarkan alat pembayaran yang sah dari suatu negara, merumuskan dan melaksanakan kebijakan moneter, mengatur dan menjaga kelancaran sistem pembayaran, mengatur dan mengawasi perbankan serta menjalan fungsi sebagai lender of the las resort. Bank sentral yang dimaksud adalah Bank Indonesia, lembaga negara yang independen dalam melaksanakan tugas dan wewenangnya, bebas dari campur tangan pemerintah dan atau pihak lain, kecuali untuk hal-hal yang secara tegas diatur dalam undand-undang ini.

2. Bank Umum

Bank umum menurut Peraturan Bank Indonesia No. 9/7/PBI/2007 adalah bank yang melaksanakan kegiatan usaha secara konvensional dan atau berdasarkan prinsip syariah dalam kegiatannya memberikan jasa dalam lalu lintas pembayaran. Jasa yang diberikan oleh bank umum bersifat umum, artinya dapat memberikan seluruh jasa perbankan yang ada. Bank umum sering disebut bank komersial.

3. Bank Perkreditan Rakyat (BPR)

Bank yang melaksanakan kegiatan usaha secara konvensional atau berdasarkan prinsip syariah yang dalam kegiatannya tidak diberikan jasa dalam lalu lintas pembayaran. Kegiatan BPR jauh lebih sempit jika dibandingkan dalam kegiatan bank umum. BPR dalam melakukan kegiatannya tidak sama dengan kegiatan yank dilakukan oleh bank konvensional (bank umum). 


\section{Jenis Bank Berdasarkan Kepemilikannya}

1. Bank Milik Pemerintah

Bank di mana baik akta pendirian maupun modalnya dimiliki oleh pemerintah, sehingga seluruh keuntungan bank dimiliki oleh pemerintah pula.

2. Bank Swasta Nasional

Bank seluruh atau sebagian besar modalnya dimiliki oleh swasta nasional serta akta pendiriannya pun didirikan oleh swasta, begitu pula pembagian keuntungannya juga dipertunjukkan untuk swasta pula.

3. Bank Milik Asing

Bank jenis ini merupakan cabang dari bank yang ada diluar negeri, baik milik swasta asing maupun pemerintah asing. Kepemilikannya dimiliki oleh pihak luar negeri.

4. Bank Milik Koperasi

Saham-saham bank ini dimiliki oleh perusahaan yang berbadan hukum koperasi.

5. Bank Milik Campuran

Saham bank ini dimiliki oleh pihak asing dan pihak swasta nasional, kepemilikan sahamnya mayoritas dimiliki oleh warga negara Indonesia.

\section{Jenis Bank Berdasarkan Segi Pengelolaannya}

1. Bank Pemerintah yaitu bank yang didirikan dengan undang-undang berdasarkan ketentuan dalam undang-undang tersebut, serta pembukaan kantor cabank dan perwakilan dari bank umum milik negaranya dapat dilakukan dengan izin Menteri Keuangan setelah mendengar pertimbangan Bank Indonesia.

2. Bank swasta yang didirikan dan menjalankan usaha sebagai bank setelah mendapat izin dari Menteri Keuangan dengan mendengar pertimbangan Bank Indonesia.

\section{Jenis Bank Berdasarkan Kegiatan Operasionalnya}

1. Bank Konvensional

Bank yang dalam operasionalnya menerapkan metode bunga, karena metode bunga sudah ada terebih dahulu, menjadi kebiasaan dan telah dipakai secara meluas dibandingkan dengan metode bagi hasil.

2. Bank Syariah

Bank syariah muncul di Indonesia pada awal tahun 1990-an. Pemrakarsa pendirian bank syariah di Indonesia dilakukan oleh Majelis Ulama Indonesia (MUI) pada tanggal 18-20 Agustus 1990. Bank yang beroperasi sesuai dengan prinsip-prinsip syariah Islam, maksudnya adalah bank yang dalam operasinya mengikuti ketentuan-ketentuan syariah Islam, khususnya yang menyangkut tata cara bermuamalah secara Islam.

\section{Jenis Bank Dilihat dari Segi Statusnya}

1. Bank Umum Devisa

Bank yang ruang lingkup operasionalnya sampai luar negeri yang berhubungan dengan mata uang asing secara keseluruhan, misalnya transfer keluar negeri.

2. Bank Umum Non Devisa

Bank ruang lingkup gerak operasionalnya didalam negeri saja yang belum mempunyai izin untuk melaksanakan transaksi sebagai bank devisa.

Dari jenis-jenis bank yang dijelaskan dapat dilihat bahwa PT. BPRS Safir Bengkulu dilihat dari fungsinya Bank Perkreditan Rakyat, dilihat dari segi pengelolaannya Bank Swasta, dilihat dari segi statusnya Bank Non Devisa dilihat dari segi kegiatan operasionalnya Bank Syariah.

\section{Informasi Akuntansi}

Temukan Pengertian (2013) mengemukakan bahwa "informasi adalah Sekumpulan data/ fakta yang diorganisasi atau diolah dengan cara tertentu sehingga mempunyai arti bagi penerim. Data yang telah diolah menjadi sesuatu yang berguna bagi si penerima maksudnya 
yaitu dapat memberikan keterangan atau pengetahuan. Dengan demikian yang menjadi sumber informasi adalah data. Informasi dapat juga di katakan sebuah pengetahuan yang diperoleh dari pembelajaran, pengalaman, atau instruksi".

Godam (2006) mendefenisikan bahwa "Akuntansi adalah suatu proses mencatat, mengklasifikasi, meringkas, mengolah dan menyajikan data, transaksi serta kejadian yang berhubungan dengan keuangan sehingga dapat digunakan oleh orang yang menggunakannya dengan mudah dimengerti untuk pengambilan suatu keputusan serta tujuan lainnya".

Jadi Informasi Akuntansi adalah suatu proses pengolahan data yang bersifat kuantitatif dalam ukuran uang bersumber dari transaksi kegiatan operasi suatu badan usaha atau unit organisasi dapat berupa laporan keuangan badan usaha atau unit organisasi tersebut untuk disampaikan kepada pihak yang memerlukan dan dapat digunakan oleh pihak yang berkepentingan dalam pemilihan berbagai alternatif keputusan ekonomi.

\section{Pengertian Laporan Keuangan}

Hery (2008:15) menyimpulkan "Laporan keuangan pada dasarnya adalah hasil dari proses akuntansi yang dapat digunakan sebagai alat untuk mengomunikasikan data keuangan atau aktivitas perusahaan kepada pihak-pihak yang berkepentingan".

Menurut IAI (Revisi 2008) tertulis bahwa "laporan keuangan adalah suatu penyajian terstruktur dari posisi keuangan dan kinerja keuangan dari suatu entitas syariah".

Pihak-pihak yang berkepentingan terhadap posisi keuangan maupun perkembangan perusahaan dibagi menjadi dua, yaitu pihak internal seperti manajemen perusahaan dan karyawan, dan yang kedua adalah pihak eksternal seperti pemegang saham, investor, kreditor, pemerintah dan masyarakat. Sehingga dapat disimpulkan bahwa laporan keuangan merupakan alat informasi yang menghubungkan perusahaan dengan pihak-pihak yang berkepentingan, yang menunjukkan kondisi kesehatan keuangan perusahaan dan kinerja perusahaan. meliputi:

Ikatan Akuntan Indonesia, Standar Akuntansi Keuangan (2009) unsur laporan keuangan

1. Aktiva adalah sumber daya yang dikuasai oleh perusahaan sebagai akibat dari peristiwa masa lalu dan dari mana manfaat ekonomi di masa depan diharapkan akan diperoleh perusahaan.

2. Kewajiban merupakan hutang perusahaan masa kini yang timbul dari peristiwa masa lalu, penyelesaiannya diharapkan mengakibatkan arus keluar dari sumber daya perusahaan yang mengandung manfaat ekonomi.

3. Ekuitas adalah hak residual atas aktiva perusahaan setelah dikurangi semua kewajiban.

4. Penghasilan (income) adalah kenaikan manfaat ekonomi selama suatu periode akuntansi dalam bentuk pemasukan atau penambahan aktiva atau penurunan kewajiban yang mengakibatkan kenaikan ekuitas yang tidak berasal dari kontribusi penanam modal.

5. Beban (Expenses) adalah penurunan manfaat ekonomi selama suatu periode akuntansi dalam bentuk arus keluar atau berkurang aktiva atau terjadinya kewajiban yang mengakibatkan penurunan ekuitas yang tidak menyangkut pembagian kepada penanam modal.

\section{Bentuk dan Penyajian Laporan Keuangan}

Laporan keuangan menggambarkan dampak keuangan dari transaksi dan peristiwa lain yang diklasifikasikan dalam beberapa besar menurut karakteristik ekonominya. Kelompok besar ini merupakan komponen laporan keuangan. Komponen yang berkaitan secara langsung dengan pengukuran posisi keuangan adalah aktivitas, hutang, dan modal. Sedang komponen yang berkaitan dengan pengukuran kinerja dalam laporan laba rugi adalah penghasilan dan beban.

Supaya laporan keuangan dapat mencapai tujuannya, maka cara penyajian harus berdasarkan prinsip akuntansi yang telah diterima secara umum. Di Indonesia cara penyajian laporan keuangan harus sesuai dengan Standar Akuntansi Keuangan. 
1) Neraca

Hery (2008:15) menyimpulkan "neraca (balance sheet) adalah sebuah laporan yang sistematis tentang posisi aktiva, kewajiban dan ekuitas perusahaan per tanggal tertentu. Tujuan neraca adalah untuk menggambarkan posisi keuangan perusahaan".

Posisi keuangan tersebut menunjukkan keadaan harta yang dimiliki perusahaan dan menunjukkan sumber darimana harta tersebut diperoleh. Adapun sumber dari mana harta diperoleh adalah dari hutang dan dari modal. Dengan perkataan lain, neraca adalah suatu laporan yang disusun secara sistematis tentang keadaan harta, hutang, dan modal perusahaan pada suatu saat tertentu.

Bentuk atau susunan neraca tiap-tiap perusahaan tidak sama, tergantung dari tujuantujuan yang akan dicapai tetapi bentuk neraca yang umum digunakan dalah sebagai barikut:

a) Bentuk perkiraan $\mathrm{T}$ atau account form, dimana setiap aktiva terletak disebalah kiri (debet) sedangkan hutang dan modal terletak di sebelah kanan (kredit).

b) Bentuk laporan report form, dimana semua aktiva terletak disebelah atas sedangkan hutang dan modalnya terletak dibawahnya.

c) Bentuk necara yang disesuaikan dengan kedudukan atau posisi keuangan perusahaan, bentuk ini bertujuan agar kedudukan atau posisi keuangan yang dikehendaki nampak dengan jelas, misalnya modal kerja netto atau modal perusahaan.

Neraca terdiri dari tiga bagian utama yaitu aktiva, hutang, dan ekuitas. Disini akan dijelaskan secara ringkas ketiga komponen utama neraca.

a) Aktiva

Jumingan (2005:13) menyimpulkan "aktiva merupakan bentuk dari penanaman modal perusahaan. Bentuknya dapat berupa harta kekayaan atau hak atas kekayaan atau jasa yang dimiliki oleh perusahaan. Harta kekayaan tersebut harus dinyatakan dengan jelas, diukur dalam satuan uang, dan urutan berdasarkan lamanya waktu atau kecepatannya berubah kembali menjadi uang kas".

Penyajian aktiva dalam neraca disusun berdasarkan urutan likuiditasnya sebagai berikut:

(1) Aktiva lancar

Aktiva lancar ialah kas/bank dan sumber-sumber lain yang dapat diharapkan dicairkan menjadi uang kas/bank, dijual atau dipakai dalam satu tahun dalam siklus kegiatan norma perusahaan jika melampaui satu tahun.

(2) Investasi jangka panjang

Merupakan bentuk penyertaan jangka panjang atau yang dimaksudkan untuk menguasai perusahaan lain.

(3) Aktiva tetap

Aktiva tetap adalah aktiva berwujud yang diperoleh dalam bentuk siap pakai atau dengan dibangun lebih dahulu, yang digunakan dalam operasi perusahaan dan mempunyai masa manfaatnya. Aktiva tetap dinyatakan sebesar nilai buku, yaitu harga peolehan dikurangi dengan akumulasi penyusutan.

(4) Aktiva tidak berwujud

Aktiva tidak berwujud adalah kekayaan perusahaan yang secara fisik tidak nampak, tetapi merupakan suatu hak yang mempunyai nilai dan dimiliki oleh perusahaan untuk digunakan dalam kegiatan perusahaan. Yang termasuk intangible fixed assets ini antara lain meliputi: hak cipta, merk dagang, biaya pendirian, lisensi, goodwill.

b) Kewajiban atau Utang

Jumingan (2005:13) menarik kesimpulan sebagai berikut:

Utang menunjukan sumber modal yang berasal dari kreditur. Dalam jangka waktu tertentu pihak perusahaan wajib membayar kembali atau wajib memenuhi tagihan yang berasal dari pihak luar tersebut. Pemenuhan kewajiban ini dapat berupa pembayaran utang, penyerahan barang tau jasa kepada pihak yang telah memberikan pinjaman kepada perusahaan. Kreditur-kreditur tersebut ada yang mendapat jaminan 
sepenuhnya dangan harta kekayaan tertentu (secured creditors), mendapat jaminan sebagian (partly secured creditors), atau tanpa jaminan sama sekali (unsecured creditors).

Kewajiban dapat diklasifikasikan sebagai berikut:

(1) Kewajiban lancar

Meliputi utang yang diharapkan akan dilunasi dalam waktu satu tahun dengan menggunakan sumber-sumber yang merupakan akiva lancar atau dengan menimpulkan utang lancar lainnya.

(2) Kewajiban jangka panjang

Utang yang tidak akan jatuh tempo dalam waktu satu tahun atau penyelesaiannya tidak menggunakan sumber-sumber yang merupakan aktiva lancar digolongkan sebagai kewajiban jangka panjang. Kewajiban jangka panjang meliputi: obligasi, pinjaman gadai, hipotik.

(3) Kewajiban-kewajiban lain

Merupakan hutang yang tidak dapat secara layak digolongkan kedalam kewajiban lancar atau kewajiban jangka panjang disajikan dalam kelompok kewajiban lainlain. Kewajiban lain-lain meliputi pendapatan yang ditangguhkan, uang jaminan jangka panjang yang diterima dari langganan, hutang pada direksi atau perusahaan.

c) Ekuitas atau modal

Jumingan (2005:13) menyimpulkan "modal merupakan sumber modal yang berasal dari pemilik perusahaan. Bersama-sama dengan modal yang berasal dari kreditur kemudian ditanamkan dalam berbagai bentuk aktiva perusahaan".

2) Laporan laba rugi

Merupakan laporang yang mencerminkan suatu kegiatan perusahaan untuk periode tertentu dan melaporkan laba rugi netto yang merupakan hasil operasional atau kegiatan tertentu.

Hery (2008:15) menyimpulkan "laporan keuangan merupakan laporan yang sistematis tentang pendapatan dan beban perusahaan untuk satu periode waktu tertentu. Laporan laba rugi ini akhirnya memuat informasi mengenai hasil usaha perusahaan, yaitu laba/rugi bersih, yang merupakan hasil dari pendapatan dikurangi beban.

3) Laporan ekuitas pemilik

Hery (2008:15) menyimpulkan "Laporan ekuitas pemilik adalah sebuah laporan yang menyajikan ikhtisar perubahan dalam ekuitas pemilik suatu perusahaan untuk satu periode waktu tertentu (laporan perubahan modal)".

Ekuitas pemilik akan bertambah dengan adanya investasi (setoran modal) dan laba bersih, sebaliknya ekuitas pemilik akan berkurang dengan adanya prive (penarikan/pengambilan untuk kepentingan pribadi) dan rugi bersih.

4) Laporan arus kas

Hery (2008:15) menyimpulkan "Laporan arus kas adalah sebuah laporan yang menggambarkan arus kas masuk dan arus kas keluar secara terperinci dari masing-masing aktivitas yaitu mulai dari aktivitas operasi, aktivitas invenstasi, sampai pada aktivitas pendanaan/pembiayaan untuk satu periode waktu tertentu". Laporan arus kas menunjukan besarnya kenaikan/penurunan bersih kas dari seluruh aktivitas selama periode berjalan serta saldo kas yang dimiliki perusahaan sampai akhir periode.

5) Catatan atas laporan keuangan

Catatan ini mengungkapkan informasi tentang dasar penyusunan laporan keuangan dan kebijakan akuntansi yang dipilih dan diterapkan terhadap peristiwa dan transaksi yang penting. Juga mengungkapkan informasi tambahan yang tidak disajikan dalam laporan keuangan tetapi diperlukan dalam rangka penyajian secara wajar.

\section{Keterbatasan Laporan Keuangan}

Laporan keuangan mempunyai beberapa keterbatasan yang penting yaitu: 
1. Laporan keuangan yang dibuat secara periodik dasarnya merupakan interm report (laporan yang dibuat antara waktu tertentu yang sifatnya sementara) dan bukan merupakan laporan final.

2. Laporan keuangan menunjukkan angka dalam rupiah yang kelihatannya bersifat pasti dan tepat, tetapi sebenarnya dasar penyusunannya dengan standar yang mungkin berbeda atau berubah-ubah.

3. Laporan keuangan disususn berdasarkan hasil pencatatan transaksi keuangan atau nilai rupaih dari berbagai waktu atau tanggal yang lalu, dimana daya beli (purchasing power) uang tersebut semakin menurun, dibandingkan dengan tahun-tahun sebelumnya, sehingga kenaikan volume penjualan yang dinyatakan dalam rupiah belum tentu menunjukan atau mencerminkan unit yang dijual semakin besar, mungkin kenaikan disebabkan naiknya harga jual barang tersebut yang mungkin juga diikuti kenaikan tingkat harga-harga.

4. Laporan keuangan tidak mencerminkan berbagai faktor yang dapat mempengaruhi posisi atau keadaan keuangan perusahaan karena faktor-faktor tersebut tidak dapat dinyatakan dengan faktor uang.

\section{Pembiayaan}

Pembiayaan adalah salah Satu penyediaan uang atau tagihan yang ... berdasarkan persetujuan atau kesepakatan antara bank syariah dan/atau UUS dan pihak lain yang mewajibkan pihak yang dibiayai dan/atau diberi fasilitas dana untuk mengembalikan dana tersebut setelah jangka waktu tertentu dengan imbalan ujrah, tanpa imbalan atau bagi hasil sebagaimana dimaksud dalam Undang-undang Nomor 21 Tahun 2008 tentang Perbankan Syariah". (Peraturan Bank Indonesia Nomor: 13/9/PBI/2011:4).

\section{Jenis-jenis Pembiayaan}

Adiwarman A. Karim (2010:231) mengatakan bahwa jenis-jenis pembiayaan antara lain:

1. Pembiayaan modal kerja, yaitu pembiayaan yang dipergunakan untuk mendukung operasional perusahaan sehari-hari sehingga perusahaan dapat beroperasi secara normal dan lancar.

2. Pembiayaan invastasi, yaitu pembiayaan yang dimaksud untuk memperoleh imbalan/manfaat/keuntungan dikemudian hari.

3. Pembiayaan konsumtif, yaitu pembiayaan yang diberikan untuk tujuan diluar usaha dan umumnya bersifat perorangan.

\section{Unsur-unsur Pembiayaan}

Kasmir (2010:108) mengatakan bahwa unsur-unsur yang terkandung dalam pemberian pembiayaan adalah sebagai berikut:

1. Kepercayaan

Keyakinan pemberian pembiayaan yang diberikan (berupa uang, barang atau jasa) akan benar-benar diterima kembali dimasa tertentu dimasa datang. Kepercayaan ini diberikan bank, dimana sebelumnya sudah dilakukan penelitian penyediaan tentang nasabah baik secara intern maupun secara ekstern. Penelitian dan penyelidikan tentang kondisi masa lalu dan sekarang terhadap nasabah permohonan pembiayaan.

2. Kesepakatan

Kesepakatan dituangan dalam suatu perjanjian dimana masing-masing pihak menandatangani hak dan kewajiban masing-masing.

3. Jangka Waktu

Setiap pembayaran yang diberikan memiliki jangka waktu tertentu. Jangka waktu ini mencakup masa pengembalian pembiayaan yang telah disepakati. Jangka waktu tesebut bisa berbentuk jangka pendek, jangka menengah atau panjang. 


\section{Resiko}

Adanya suatu tenggang waktu pengembalian akan menyebabkan suatu resiko tidak tertagihnya/macet pemberian pembiayaan. Semakin panjang suatu pembiayaan semangkin rentan resiko yang dihadapi demikian sebaliknya. Resiko ini ditanggung oleh bank, baik resiko yang disengaja oleh nasabah yang lalai, maupun oleh resiko yang tidak disengaja. Misalnya terjadi bencana alam atau bangkrutnya usaha nasabah tanpa ada unsur kesengajaan lainnya.

5. Balas Jasa

Balas jasa dalam bentuk bunga dan biaya administrasi pembiayaan ini merupakan keuntungan bank. Sedangkan bank yang berprinsip syariah balas jasanya ditentukan dengan bagi hasil.

\section{Analisis Pemberian Pembiayaan}

Kasmir (2008:109) mengatakan bahwa pertimbangan yang digunakan untuk mengevaluasi calon nasabah yaitu dengan prinsip 5C:

1. Character

Suatu keyakinan bahwa, sifat atau watak dari orang-orang yang akan diberikan pembiayaan benar-benar dapat dipercaya, hal ini tercermin dari latar belakang nasabah baik dari pekerjaan maupun sifatnya.

2. Capacity

Untuk melihat nasabah dalam kemampuannya dibidang bisnis yaitu dihubungkan dengan pendidikannya dan juga diukur dengan kemamuannya dalam memahami tentang ketentuan-ketentuan pemerintah.

3. Capital

Untuk melihat penggunaan modal apakah efektif, dengan melihat laporan keuangan (neraca dan laporan rugi laba) dengan melakukan pengukuran seperti dari segi likuiditas solvabilitas rentabilitas, dan ukuran lainnya.

4. Colleteral

Merupakan jaminan yang diberikan calon nasabah baik yang bersifat fisik maupun non fisik. Jaminan hendaknya melebihi jumlah pembiayaan yang diberikan dan juga harus diteliti keabsahannya.

5. Condition

Menilai kondisis ekonomi dan politik sekarang dan di masa yang akan datang sesuai sektor masing-masing, serta prospek usaha dari sektor yang dijalankan oleh calon nasabah.

\section{Kerangka Analisis}

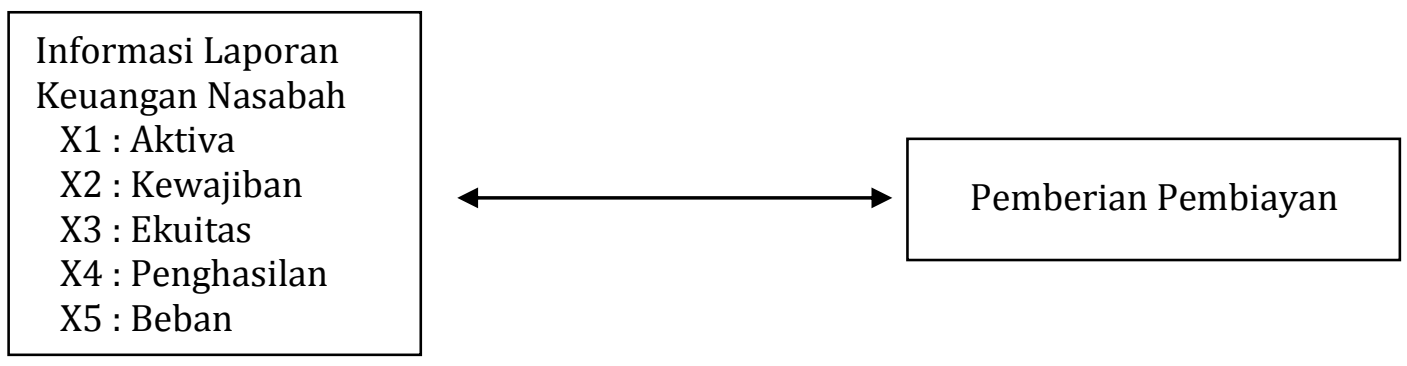

Gambar 1. Kerangka Analisis 


\section{HASIL DAN PEMBAHASAN \\ Uji Validitas dan Reliabilitas}

a. Uji Validitas Data

Uji validitas dilakukan dengan mengukur 15 sempel karyawan pada PT. BPRS Safir Bengkulu yang diolah dengan menggunakan SPSS 15.0 for Windows. Hasil dari uji validitas menunjukan bahwa nilai KMO sebesar 0.723 menandakan bahwa instrumen valid karena sudah memenuhi batas $0.50(0.723>0.50)$. Dan dengan melihat component matrix bahwa seluruh item meliputi aktiva (X1), kewajiban (X2), ekuitas (X3), penghasilan (X4), beban $(\mathrm{X} 5)$, dan pemberian pembiayaan $(\mathrm{Y})$ memiliki loading faktor yang besar yaitu diatas 0.50 . dengan demikian dapat dibuktikan 6 item valid.

b. Uji Reliabilitas Data

Uji reabilitas diukur dengan menggunakan cronbach 's alpha $(\alpha)$ dimana hasil menunjukkan diatas 0.70 dapat dikatakan reliabel. Sementara hasil uji menunjukan cronbach 's alpha sebesar 0.932, dengan demikian dapat disimpulkan bahwa variabel ini adalah reliabel.

\section{Uji Hipotesis}

a. Uji Spearman Rho

1. Hubungan Antara Aktiva dengan Keputusan Pemberian Pembiayaan

Hubungan antara aktiva dengan keputusan pemberian pembiayaan dianalisis dengan menggunakan uji korelasi spearman rank yang diolah dengan SPSS 15.0 for Windows. Dari hasil uji ini diperoleh nilai korelasi spearman rank antara aktiva dengan keputusan pemberian pembiayaan adalah sebesar 0.739 , rho hitung $0.739>$ rho $_{\text {tabel }} 0.521$ maka $\mathrm{H}_{0}$ ditolak. Hal ini berarti terdapat hubungan yang substansial antara aktiva dengan pemberian keputusan pembiayaan. Tingkat signifikasi sebesar $0.000 \leq \alpha$ maka $\mathrm{H}_{0}$ ditolak, yang berarti ada hubungan yang signifikan pada taraf nyata 0.05 dan taraf nyata 0.01 .

2. Hubungan Antara Kewajiban dengan Keputusan Pemberian Pembiayaan

Hubungan antara kewajiban dengan keputusan pemberian pembiayaan dianalisis dengan menggunakan uji korelasi spearman rank yang diolah dengan SPSS 15.0 for Windows. Dari hasil uji ini diperoleh nilai korelasi spearman rank antara kewajiban dengan keputusan pemberian pembiayaan adalah sebesar 0.637 , rho hitung $0.637>$ rhotabel $_{\text {ta }}$ 0.521 maka $\mathrm{H}_{0}$ ditolak. Hal ini berarti terdapat hubungan yang substansial antara kewajiban dengan pemberian keputusan pembiayaan. Tingkat signifikasi sebesar 0.000 $\leq \alpha$ maka $\mathrm{H}_{0}$ ditolak, yang berarti ada hubungan yang signifikan pada taraf nyata 0.05 .

3. Hubungan Antara Ekuitas dengan Keputusan Pemberian Pembiayaan

Hubungan antara ekuitas dengan keputusan pemberian pembiayaan dianalisis dengan menggunakan uji korelasi spearman rank yang diolah dengan SPSS 15.0 for Windows. Dari hasil uji ini diperoleh nilai korelasi spearman rank antara ekuitas dengan keputusan pemberian pembiayaan adalah sebesar 0.439 , rho hitung $0.439>$ rho $_{\text {tabel }} 0.521$ maka $\mathrm{H}_{0}$ diterima. Hal ini berarti tidak terdapat hubungan yang substansial antara ekuitas dengan pemberian keputusan pembiayaan. Tingkat signifikasi sebesar $0.000 \leq \alpha$ maka $\mathrm{H}_{0}$ diterima, yang berarti tidak ada hubungan yang signifikan pada taraf nyata 0.05 .

4. Hubungan Antara Penghasilan dengan Keputusan Pemberian Pembiayaan Hubungan antara penghasilan dengan keputusan pemberian pembiayaan dianalisis dengan menggunakan uji korelasi spearman rank yang diolah dengan SPSS 15.0 for Windows. Dari hasil uji ini diperoleh nilai korelasi spearman rank antara penghasilan dengan keputusan pemberian pembiayaan adalah sebesar 0.617 , rho hitung $0.617>$ rhotabel 0.521 maka $\mathrm{H}_{0}$ ditolak. Hal ini berarti terdapat hubungan yang substansial antara penghasilan dengan pemberian keputusan pembiayaan. Tingkat signifikasi sebesar $0.000 \leq \alpha$ maka $\mathrm{H}_{0}$ ditolak, yang berarti ada hubungan yang signifikan pada taraf nyata 0.05 . 
5. Hubungan Antara Beban dengan Keputusan Pemberian Pembiayaan

Hubungan antara beban dengan keputusan pemberian pembiayaan dianalisis dengan menggunakan uji korelasi spearman rank yang diolah dengan SPSS 15.0 for Windows. Dari hasil uji ini diperoleh nilai korelasi spearman rank antara beban dengan keputusan pemberian pembiayaan adalah sebesar 0.639 , rho hitung $_{0.639}>$ rhotabel 0.521 maka $\mathrm{H}_{0}$ ditolak. Hal ini berarti terdapat hubungan yang substansial antara beban dengan pemberian keputusan pembiayaan. Tingkat signifikasi sebesar $0.000 \leq \alpha$ maka $\mathrm{H}_{0}$ ditolak, yang berarti ada hubungan yang signifikan pada taraf nyata 0.05 .

b. Uji F-test

Uji F digunakan untuk mengetahui apakah variabel-variabel independen secara simultan berpengaruh signifikan terhadap variabel dependen yang diolah dengan SPSS 15.0 for Windows. Dengan taraf nyata yang digunakan adalah 0.05 . Apabila nilai $\mathrm{F}$ hasil dari perhitungan lebih besar dari pada nilai $\mathrm{F}$ menurut tabel maka hipotesis alternatif yang menyatakan bahwa semua variabel independen secara simultan berpengaruh signifikan terhadap variabel dependen.

Tabel 2. Uji F

\begin{tabular}{|ll|r|r|r|r|r|}
\hline Model & & Sum of & df & Mean Square & F & Sig. \\
\hline 1 & Regression & 13,771 & 5 & 2,754 & 4,253 &, $029^{9}$ \\
& Residual & 5,829 & 9 &, 648 & & \\
& Total & 19,600 & 14 & & & \\
\hline
\end{tabular}

a. Predictors: (Constant), X5, X3, X2, X1, X4

b. Dependent Variable: $Y$

Dari tabel diatas menunjukan bahwa nilai $\mathrm{F}_{\text {hitung }}$ sebesar 4.253 , sedangkan nilai $\mathrm{F}_{\text {tabel }}$ sebesar 3.48 dengan tingkat (sig) 0.029 yang berarti probabilitas lebih kecil dari 0.05 maka ditolak. Maka dapat disimpulkan bahwa terdapat pengaruh signifikan antara informasi laporan keuangan nasabah (aktiva, kewajiban, ekuitas, penghasilan dan beban) terhadap pemberian pembiayaan atau secara simultan (bersama-sama) informasi laporan keuangan nasabah (aktiva, kewajiban, ekuitas, penghasilan dan beban) terhadap pemberian pembiayaan.

c. Uji t-test

Uji t digunakan untuk mengetahui apakah variabel-variabel independen secara parsial berpengaruh nyata atau tidak terhadap variabel dependen yang diolah dengan SPSS 15.0 for Windows. Dengan derajat signifikan yang digunakan adalah 0.05. Apabila nilai signifikan lebih kecil dari derajat signifikan maka hipotesis alternatif yang menyatakan bahwa suatu variabel independen secara parsial mempengaruhi variabel dependen.

Tabel 3. Uji t

\begin{tabular}{|c|c|c|c|c|c|c|c|c|}
\hline \multirow[b]{2}{*}{ Mod } & & \multicolumn{2}{|c|}{$\begin{array}{l}\text { Unstandardized } \\
\text { Coefficients }\end{array}$} & \multirow{2}{*}{$\begin{array}{c}\text { Standardized } \\
\text { Coefficients }\end{array}$} & \multirow[b]{2}{*}{$t$} & \multirow[b]{2}{*}{ Sig. } & \multicolumn{2}{|c|}{ Collinearity Statistics } \\
\hline & & B & Std. Error & & & & Tolerance & VIF \\
\hline & (Constant) & 1,725 & 2,999 & &, 575 &, 579 & & \\
\hline & $\mathrm{X} 1$ & 1,819 & ,840 & 1,522 & 2,166 & ,059 & ,067 & 14,955 \\
\hline & $\times 2$ & 1,426 & ,881 & 1,497 & 1,618 & , 140 & ,039 & 25,887 \\
\hline & $\mathrm{X} 3$ &,- 363 & ,239 &,- 429 & $-1,521$ & , 163 & ,416 & 2,404 \\
\hline & $\mathrm{X} 4$ & $-1,188$ & 928 & $-1,251$ & $-1,280$ & 233 & .035 & 28,919 \\
\hline & $\mathrm{X} 5$ &,- 812 & ,928 &,- 676 &,- 875 &, 404 &, 055 & 18,097 \\
\hline
\end{tabular}

a. Dependent Variable: $Y$

Dari tabel diatas menunjukan bahwa tidak ada pengaruh yang signifikan antara informasi laporan keuangan nasabah (aktiva, kewajiban, ekuitas, penghasilan dan beban) dengan keputusan pemberian pembiayaan ini disebabkan karena nilai constant dari tabel diatas memiliki nilai sebesar 0.579 ini berarti nilai constant lebih besar dari taraf nyata yang digunakan yaitu sebesar 0.05 . 
d. Koefisien Dereminan $\left(\mathrm{R}^{2}\right)$

Koefisien dereminasi digunakan untuk mengetahui seberapa besar hubungan dari beberapa variabel dalam pengertian yang lebih jelas. Koefisien dereminasi akan menjelaskan seberapa besar perubahan atau variasi suatu variabel bisa dijelaskan oleh perubahan atau variazi pada variabel yang lain.

Tabel.4 Koefisien Dereminan ( $\left.\mathrm{R}^{2}\right)$

\begin{tabular}{|l|r|r|r|r|}
\hline Model & \multicolumn{1}{|c|}{$R$} & R Square & $\begin{array}{c}\text { Adjusted R } \\
\text { Square }\end{array}$ & $\begin{array}{c}\text { Std. Error of } \\
\text { the Estimate }\end{array}$ \\
\hline 1 &, $838^{9}$ &, 703 &, 537 &, 805 \\
\hline
\end{tabular}

a. Predictors: (Constant), $\times 5, \times 3, \times 2, \times 1, \times 4$

b. Dependent Variable: $Y$

Uji determinasi menunjukan bahwa nilai R Square sebesar 0.703 hal ini menunjukan bahwa informasi laporan keuangan nasabah (aktiva, kewajiban, ekuitas, penghasilan dan beban) berpengaruh $70.3 \%$ dengan keputusan pemberian pembiayaan dan sisanya $29.7 \%$ dipengaruhi oleh variabel lain yang tidak diteliti.

\section{Pembahasan}

Berdasarkan hasil uji korelasi rank spearman yang telah dilakukan, maka dapat diketahui bahwa masing-masing variabel ada yang memiliki hubungan dan ada yang tidak memiliki hubungan. Variabel yang memiliki hubungan antara aktiva, kewajiban, penghasilan dan beban dengan keputusan pemberian pembiayaan dan variabel yang tidak memiliki hubungan antara ekuitas dengan keputusan pemberian pembiayaan.

Masing-masing variabel informasi laporan keuangan nasabah tidak semuanya memiliki hubungan positif dengan variabel pemberian pembiayaan. Hal ini terjadi karena variabel ekuitas tidak hanya menilai keseriusan calon nasabah untuk menjalankan usaha dari besarnya jumlah ekuitas yang akan ditanamkan oleh calon nasabah kedalam usaha yang akan dibiayai dengan dana bank. Namun, PT. BPRS Safir Bengkulu lebih mempertimbangkan jumlah harta yang dimiliki, kesanggupan pembayaran hutang, penghasilan yang diperolehnya dan beban yang ditanggung setiap bulannya.

Dari uji F-test yang dilakukan menunjungkan secara simultan (bersama-sama) bahwa variabel informasi laporan keuangan nasabah (aktiva, kewajiban, ekuitas, penghasilan dan beban) memiliki pengaruh dengan keputusan pemberian pembiayaan.

Dari uji t-test yang dilakukan menunjukan secara parsial (sendiri-sendiri) bahwa semua variabel informasi laporan keuangan nasabah tidak memiliki pengaruh dengan keputusan pemberian pembiayaan.

Dan dari uji koefisien dereminan yang dilakukan yaitu informasi laporan keuangan nasabah memiliki pengaruh pengaruh sebesar $70.3 \%$ dengan keputusan pemberian pembiayaan.

\section{Kesimpulan}

Hasil penelitian yang telah dilakukan dengan menggunakan korelasi rank spearman, menghasilkan kesimpulan sebagai berikut:

a. Terdapat hubungan yang memiliki pengaruh antara informasi laporan keuangan nasabah (aktiva) dengan keputusan pemberian pembiayaan.

b. Terdapat hubungan yang memiliki pengaruh antara informasi laporan keuangan nasabah (kewajiban) dengan keputusan pemberian pembiayaan.

c. Tidak terdapat hubungan namun tidak memiliki pengaruh antara informasi laporan keuangan nasabah (ekuitas) dengan keputusan pemberian pembiayaan. 
d. Terdapat hubungan yang memiliki pengaruh antara informasi laporan keuangan nasabah (penghasilan) dengan keputusan pemberian pembiayaan.

e. Terdapat hubungan yang memiliki pengaruh antara informasi laporan keuangan nasabah (beban) dengan keputusan pemberian pembiayaan.

\section{Saran}

Hasil penelitian yang telah dilakukan, maka saran yang dapat diberikan kepada PT. BPRS Safir Bengkulu adalah sebagai dalam proses pelaksanaan pemberian pembiayaan sebaiknya bagian marketing memberikan penjelasan mendetail mengenai fungsi dan tujuan dari setiap informasi laporan keuangan nasabah yang dibuat oleh setiap calon nasabah sehingga calon nasabah dapat mengerti dan memahami semua yang dianalisis oleh PT. BPRS Safir Bengkulu.

Dalam hal ini PT. BPRS Safir Bengkulu harus lebih ketat dan teliti dalam menganalisa pemberian pembiayaan terhadap calon nasabah sehingga pengambilan keputusan pemberian pembiayaan kemudian hari tidak menjadi pembiayaan macet yang merugikan pihak bank.

\section{DAFTAR PUSTAKA}

Ghozali, Imam, 2009. Aplikasi Analisis Multivariate dengan Program SPSS. Semarang: Badan Penerbit Universitas Diponegoro.

Godam, 2006. Pengertian dan Penjelasan Dasar Akuntansi - Definisi, Arti, Fungsi dan Kegunaan Belajar Ilmu Akutansi / Accounting.

http://www.organisasi.org/1970/01/pengertian-dan-penjelasan-dasar-akuntansi-definisi-artifungsi-dan-kegunaan-belajar-ilmu-akutansi-accounting.html

Hery, 2006. Pengatar Akuntansi 1. Jakarta: Lembaga Penerbit Fakultas Ekonomi Universitas Indonesia.

Jumingan, 2005. Analisis Laporan Keuangan. Surakarta: Bumi Aksara.

Karim, Adiwarman A, 2011. Bank Islam: Analisis Fiqih dan Keuangan. Edisi ke-4, Jakarta: Rajawali Pers.

Kasmir, 2010. Bank dan Lembaga Keuangan Lainnya. Jakarta: PT. Raja Grafindo Persada.

Peraturan Bank Indonesia Nomor: 13/9/PBI/2011 tentang Restrukturisasi Pembiayaan Bagi Bank Syariah dan Unit Usaha Syariah.

Peraturan Bank Indonesia Nomor: 9/7/PBI/2007 tentang Perubahan Atas Peraturan Bank Indonesia Nomor 8/3/PBI/2006 Tentang Perubahan Kegiatan Usaha Bank Umum Konvensional Menjadi Bank Umum Yang Melaksanakan Kegiatan Usaha Berdasarkan Prinsip Syariah Dan Pembukaan Kantor Bank Yang Melaksanakan Kegiatan Usaha Berdasarkan Prinsip Syariah Oleh Bank Umum Konvensional.

PSAK No.102 Akuntansi Murabahah Ikatan Akuntansi Indonesia.

Sugiyono, 2011. Metode Penelitian Kombinasi (Mixed Methods). Yogyakarta: Alfabera

Sugiyono, 2011. Statistik Nonparametris untuk Penelitian. Bandung: Alfabeta.

Temukan Pengertian, 2013. Pengertian Informasi

http://temukanpengertian.blogspot.com/2013/07/pengertian-informasi.html 
Undang-undang Nomor 10 Tahun 1998 tentang Perubahan Atas Undang-undang Nomor 7 Tahun 1992 Tentang Perbankan.

Undang-undang Republik Indonesia Nomor 3 Tahun 2004 tentang Perubahan Atas Undangundang Republik Indonesia Nomor 23 Tahun 1999 Tentang Bank Indonesia 